Wahyudin, A. • F.Y. Wicaksono $\cdot$ A.W. Irwan $\cdot$ Ruminta $\cdot$ R. Fitriani

\title{
Respons tanaman kedelai (Glycine max) varietas Wilis akibat pemberian berbagai dosis pupuk $N, P, K$, dan pupuk guano pada tanah Inceptisol Jatinangor
}

\section{Response of soybean (Glycine max) var. Wilis due to application of N, $P, K$ and guano fertilizer dosages on Inceptisols Jatinangor}

Diterima : 17 Agustus 2017/Disetujui : 25 Agustus 2017 / Dipublikasikan : 31 Agustus 2017

CDepartment of Crop Science, Padjadjaran University

\begin{abstract}
Abstarct This research aims to know the effect of Guano fertilizer application in reducing the uses of NPK fertilizer. The experiment was conducted at the Green House of Agriculture Faculty, University of Padjadjaran, Jatinangor with altitude $754 \mathrm{~m}$ up sea level and Inceptisol soil types with $\mathrm{pH}$ 6,18.

The Experiment was arranged in Randomized Block Design, with 8 treatment combinations several dosages of fertilizer differ from $100 \%$ N,P,K, 100\% Guano, 75\% N,P,K + 100\% Guano, $50 \%$ N,P,K $+100 \%$ Guano, $75 \%$ N,P,K $+75 \%$ Guano, $50 \%$ N,P,K + 75\% Guano, 75\% N,P,K + $50 \%$ Guano serta $50 \%$ N,P,K $+50 \%$ Guano and four replications, thus there are 32 units of the experiment.

The results showed that the treatments of $\mathrm{N}, \mathrm{P}, \mathrm{K}$ fertilizer and guano fertilizer in several dosages influenced on plant height, plant dry weight, biomass of plant, number of effective root nodules, number of filled pods per plant, the number of emptied pods per plant, seed weight per plant, 100 seed weight, harvest index, and seed weight per hectare. However, the treatment of $50 \% \mathrm{~N}, \mathrm{P}, \mathrm{K}+50 \%$ Guano was not significant with control influenced on plant height, biomass of plant, leaves area index, number of leaves, number of filled pods per plant, the number of emptied pods per plant, seed weight per plant, 100 seed weight, harvest index, and seed weight per hectare.
\end{abstract}

Keywords: Glycine max • N,P,K Fertilizer • Guano fertilizer

\footnotetext{
Dikomunikasikan oleh Anne Nuraini

Wahyudin, A. ${ }^{1}$ F.Y. Wicaksono ${ }^{1} \cdot$ A.W. Irwan ${ }^{1} \cdot$ Ruminta $^{1}$.

R. Fitriani ${ }^{2}$

1) Staf pengajar program studi Agroteknologi

2) Alumni program studi Agroteknologi

korespondensi: agus.wahyudin@unpad.ac.id
}

Sari Penelitian ini bertujuan untuk melihat apakah pemberian Pupuk Organik Padat Guano dapat mengurangi penggunaan Pupuk N,P,K. Percobaan dilakukan di Rumah Kaca Fakultas Pertanian Universitas Padjadjaran, Jatinangor dengan ketinggian $754 \mathrm{~m}$ di atas permukaan laut (dpl) dan menggunakan tanah inceptisol dengan pH 6,18.

Rancangan percobaan yang digunakan adalah Rancangan Acak Kelompok, terdiri dari 8 perlakuan kombinasi dosis pupuk, yang terdiri dari $100 \%$ N,P,K, $100 \%$ Pupuk Guano, $75 \%$ N,P,K + 100\% Pupuk Guano, 50\% N,P,K + 100\% Pupuk Guano, $75 \%$ N,P,K $+75 \%$ Pupuk Guano, $50 \%$ N,P,K + 75\% Pupuk Guano, 75\% N,P,K + $50 \%$ Pupuk Guano serta 50\% N,P,K + 50\% Pupuk Guano. Percobaan diulang sebanyak 4 kali, dengan demikian terdapat 32 satuan percobaan.

Hasil percobaan menunjukkan bahwa pemberian beberapa dosis pupuk N,P,K dan pupuk guano memberikan pengaruh terhadap tinggi tanaman, bobot kering tanaman, biomassa tanaman, jumlah bintil akar efektif, jumlah polong isi per tanaman, jumlah polong hampa per tanaman, bobot biji per tanaman, bobot 100 biji, indeks panen, bobot biji per hektar. Perlakuan $50 \%$ N,P,K $+50 \%$ Pupuk Guano memberikan hasil yang tidak berbeda nyata dengan perlakuan $100 \%$ NPK pada tinggi tanaman, biomassa tanaman, indeks luas daun, jumlah daun, jumlah polong isi per tanaman, jumlah polong hampa per tanaman, bobot biji per tanaman, bobot 100 biji, indeks panen serta bobot biji per hektar.

Kata kunci: Tanaman kedelai - Pupuk N,P,K • Pupuk Guano 


\section{Pendahuluan}

Kedelai (Glycine max) adalah komoditas tanaman pangan terpenting ketiga setelah padi dan jagung. Kedelai berperan sebagai sumber protein nabati yang sangat penting dalam rangka peningkatan gizi masyarakat karena aman bagi kesehatan dan murah harganya. Kedelai dapat diolah sebagai bahan industri olahan pangan seperti tahu, tempe, kecap, susu kedelai, tauco, snack dan sebagainya.

Varietas unggul bukan satu-satunya faktor yang mendukung peningkatan produksi, namun dalam sejarah tampak bahwa dalam setiap kebangkitan atau lompatan produksi pertanian, senantiasa tidak terlepas dari kontribusi digunakannya varietas unggul baru. Peningkatan produksi dan perluasan areal tanam kedelai besar-besaran pada tahun 70-an antara lain karena kontribusi yang besar daari varietas Orba. Demikiana juga lonjakan produksi kedelai yang terjadi pada awal tahun 80-an didukung oleh ditemukannya varietas unggul Wilis.

Wilis cocok ditanam pada lahan bekas padi sawah dengan pengolahan minimal atau tanpa pengolahan tanah. Umur matang Wilis 88 hari, tipe batang tegap dan tidak mudah rebah. Kecambah mempunyai vigor yang baik, pertumbuhannya cepat, dan dapat tumbuh baik pada lahan yang berdrainase kurang baik (Sumarno, 1990).

Varietas unggul merupakan komponen teknologi yang paling cepat diadopsi petani, karena mudah, murah dan kompatibel dengan teknologi lain. Dengan digunakannya varietas unggul, berarti sebagian masalah produksi seperti kemasaman, kahat atau ketidakseimbangan hara, serta cekaman hama atau penyakit telah atau lebih mudah diatasi (Suhartina, 2005).

Penggunaan pupuk sebagai salah satu usaha untuk meningkatkan produksi tanaman sudah sangat membudaya dan para petani telah menganggap bahwa pupuk dan cara pemupukan sebagi salah satu hal yng tidak dapat dipisahkan dalam kegiatan usaha taninya.

Keberhasilan pembangunan pertanian tidak dipisahkan dari kesadaran petani dalam menggunakan pupuk anorganik atau pupuk kimia dan sebagian menyebutnya pupuk buatan. Hingga awal tahun 1970 -an, pada saat petani belum menggunakan pupuk anorganik, hasil padi varietas lokal yang diusahakan hanya mampu berproduksi 2,0-2,5 t/ha, meskipun mereka telah menggunakan pupuk kandang. Dengan menggunakan pupuk anorganik, hasil varietas unggul padi di lahan sawah irigasi meningkat lebih dua kali lipat menjadi 5-6 t/ ha.

Di satu sisi, penggunaan pupuk anorganik berdampak positif terhadap peningkatan produksi tanaman, namun di sisi lain pupuk anorganik juga dapat berdampak negatif, seperti pencemaran lingkungan dan inefisiensi pemupukan di sebagian besar daerah intensifikasi tanaman pangan. Hal ini mendorong tingginya tingkat ketergantungan petani terhadap pupuk anorganik, bahkan mereka seringkali menggunakan jumlah yang berlebihan. Selain tidak lagi meningkatkan hasil, penggunaan pupuk anorganik dengan takaran di atas kebutuhan tanaman juga mengurangi keuntungan yang dapat diperoleh dari usaha tani.

Untuk mengurangi penggunaan pupuk anorganik, maka perlu digunakan pupuk organik. Pupuk organik adalah pupuk yang sebagian besar atau seluruhnya terdiri dari bahan organik yang berasal dari tanaman dan atau hewan yang telah melalui proses rekayasa, dapat berbentuk padat atau cair yang digunakan untuk mensuplai bahan organik; memperbaiki sifat fisik, kimia dan biologi tanah (Sudirja, 2007).

Pupuk organik padat umumnya merupakan pupuk lengkap karena mengandung unsur makro dan mikro meskipun dalam jumlah sedikit (Prihmantoro, 1996). Penggunaan pupuk kandang atau kompos selama ini diyakini dapat mengatasi permasalahan yang ditimbulkan oleh pupuk anorganik. Penambahan bahan organik padat akan meningkatkan hara dalam tanah secara lengkap seperti hara $\mathrm{N}, \mathrm{P}, \mathrm{K}, \mathrm{S}$ dan hara lainnya. Disamping itu akan meningkatkan kemampuan tanah untuk mengikat hara, sehingga hara akan lebih tersedia dalam kurun waktu yang relatif lama, sehingga menjamin keberlanjutan kesuburan. Hal ini dikarenakan selama proses dekomposisi bahan organik akan dihasilkan humus (koloid organik) yang dapat menahan unsur hara dan air, sehingga dapat meningkatkan daya simpan pupuk dan air di tanah. Kelebihan pupuk organik yang lain mampu menetralkan $\mathrm{pH}$ tanah, dapat meningkatkan $\mathrm{pH}$ tanah di tanah yang masam, dan dapat menurunkan $\mathrm{pH}$ tanah di tanah yang alkali, sehingga mampu menjamin $\mathrm{pH}$ tanah sesuai untuk pertumbuhan tanaman.

Salah satu jenis pupuk organik adalah guano. Penellitian tentang penggunaan pupuk guano, baik guano nitrogen maupun guano 
fosfat, masih terbatas. Suwarno (1998) dalam percobaan pot di rumah kaca tentang penggunaan guano fosfat pada tanaman kedelai yang ditanam pada tanah ordo Andisol dari Kanuma, Tochigi memperoleh hasil bahwa produksi tanaman pada perlakuan guano fosfat tidak berbeda nyata dengan produksi pada perlakuan super fosfat (SP36). Nilai efektivitas agronomis relatif (relative agronomic effective-ness, RAE) guano fosfat terhadap super fosfat (sebagai standar) pada tanaman tersebut mencapai $108 \%$ (Suwarno dan Komaruddin Idris, 2007).

Faktor dominan penyebab rendahnya produktivitas tanaman kedelai salah satunya adalah tingkat kesuburan lahan yang terus menurun (Adiningsih, dkk., 1994). Cara budidaya petani yang menerapkan budidaya konvensional dan kurang inovatif seperti ditandai dengan penggunaan input pupuk kimia yang terus menerus, tidak menggunakan pergiliran tanaman, kehilangan pasca panen yang masih tinggi $15-20 \%$ dan memakai air irigasi yang tidak efisien. Akibatnya antara lain berdampak pada rendahnya produktivitas yang mengancam kelangsungan usaha tani dan daya saing komoditi tanaman pangan yang diusahakan menyebabkan turunnya minat petani untuk mengembangkan usaha budidaya pangannya, sehingga dalam skala luas mempengaruhi produksi nasional. Tujuan penelitian ini untuk melihat apakah pemberian pupuk organik guano dapat mengurangi penggunaan pupuk N, P dan K.

\section{Bahan dan Metode}

Penelitian ini dilakukan di dalam Rumah Kaca Fakultas Pertanian Universitas Padjadjaran dengan ketinggian tempat $754 \mathrm{~m}$ di atas permukaan laut (dpl), dengan menggunakan jenis tanah Inceptisol.

Bahan yang digunakan dalam penelitian ini adalah benih kedelai varietas Wilis, diperoleh dari Ballitkabi (dengan daya berkecambah 98\% dilakukan test daya berkecambah menggunakan kertas merang), pupuk fresh guano yang diperoleh dari CV. Sari Dele, Pupuk Urea, SP-36 dan $\mathrm{KCl}$, Inokulan Rhizobium Rhizo-Plus diperoleh dari PT. Hobsanol, Insektisida Decis 2.5 EC untuk mengendalikan hama dan fungisida. Sedangkan alat-alat yang digunakan adalah Polibag kapasitas $10 \mathrm{~kg}$ dengan ukuran 30 x 40 $\mathrm{cm}$ untuk media tanam, meteran untuk mengukur tinggi tanaman, label dan plang papan nama, oven (untuk mengeringkan sampel tanaman), neraca analitik (untuk menimbang sampel tanaman), kamera (untuk dokumentasi selama penelitian) dan alat tulis.

Penelitian ini menggunakan metode percobaan Rancangan Acak Kelompok (RAK), terdiri dari 8 perlakuan kombinasi dosis pupuk dan percobaan diulang sebanyak 4 kali, dengan demikian terdapat 32 satuan percobaan. Adapun dosis pupuk yang diberikan sebagai berikut : A $=100 \% \mathrm{~N}, \mathrm{P}, \mathrm{K}$ (kontrol) $=50 \mathrm{~kg} /$ ha Urea $=0,4$ $\mathrm{g} /$ tanaman, $75 \mathrm{~kg} / \mathrm{ha} \mathrm{SP}-36=0,6 \mathrm{~g} /$ tanaman dan $100 \mathrm{~kg} / \mathrm{ha} \mathrm{KCl}=0,8 \mathrm{~g} /$ tanaman, $\mathrm{B}=100 \%$ Pupuk Guano anjuran kemasan $=1000 \mathrm{~kg} / \mathrm{ha}$ setara dengan 8,3 g/tanaman, $\mathrm{C}=75 \% \mathrm{~N}, \mathrm{P}, \mathrm{K}+$ $100 \%$ Pupuk Guano, D $=50 \%$ N,P,K $+100 \%$ Pupuk Guano, E $=75 \%$ N,P,K $+75 \%$ Pupuk Guano, $\mathrm{F}=50 \% \mathrm{~N}, \mathrm{P}, \mathrm{K}+75 \%$ Pupuk Guano, $\mathrm{G}=$ $75 \% \mathrm{~N}, \mathrm{P}, \mathrm{K}+50 \%$ Pupuk Guano, $\mathrm{H}=50 \% \mathrm{~N}, \mathrm{P}, \mathrm{K}$ $+50 \%$ Pupuk Guano.

\section{Hasil dan Pembahasan}

Tinggi Tanaman. Tinggi tanaman pada minggu ke-2 dan ke-4 tidak berbeda nyata antar perlakuan. Tinggi tanaman secara umum menunjukkan kenaikan. Perlakuan pupuk organik belum mempengaruhi tinggi tanaman. Hal ini disebabkan oleh pupuk organik lebih lama terserap tanaman dibandingkan dengan pupuk N,P,K,

Tabel 1. Pengaruh Beberapa Dosis Pupuk N,P,K dan Pupuk Guano terhadap Tinggi Tanaman 2,4,6 dan 8 MST (cm).

\begin{tabular}{ccccc}
\hline \hline Perlakuan & 2 MST & 4 MST & 6 MST & 8 MST \\
\hline A & $17,54 \mathrm{a}$ & $25,22 \mathrm{a}$ & $43,22 \mathrm{c}$ & $49,93 \mathrm{~b}$ \\
B & $15,59 \mathrm{a}$ & $24,77 \mathrm{a}$ & $41,09 \mathrm{~d}$ & $42,00 \mathrm{c}$ \\
C & $17,49 \mathrm{a}$ & $27,22 \mathrm{a}$ & $45,91 \mathrm{ab}$ & $54,05 \mathrm{ab}$ \\
D & $17,00 \mathrm{a}$ & $25,72 \mathrm{a}$ & $44,55 \mathrm{bc}$ & $52,86 \mathrm{~b}$ \\
E & $16,56 \mathrm{a}$ & $26,48 \mathrm{a}$ & $45,77 \mathrm{ab}$ & $53,86 \mathrm{ab}$ \\
F & $16,29 \mathrm{a}$ & $27,39 \mathrm{a}$ & $46,48 \mathrm{a}$ & $58,30 \mathrm{a}$ \\
G & $16,17 \mathrm{a}$ & $27,86 \mathrm{a}$ & $46,75 \mathrm{a}$ & $58,44 \mathrm{a}$ \\
H & $16,05 \mathrm{a}$ & $26,79 \mathrm{a}$ & $44,15 \mathrm{c}$ & $52,28 \mathrm{~b}$ \\
\hline \hline
\end{tabular}

$\overline{\text { Keterangan. Nilai rata-rata diikuti oleh huruf yang }}$ sama pada kolom yang sama menunjukkan tidak berbeda nyata menurut Uji Jarak Berganda Duncan pada taraf $5 \%$.

Pada minggu ke enam dan ke delapan setelah tanam, mulai terlihat perbedaan tinggi tanaman antar perlakuan. Perlakuan F $(50 \%$ NPK + 75\% Pupuk Guano) dan G (75\% NPK + $50 \%$ Pupuk Guano) menghasilkan tinggi tanaman tertinggi pada tanaman kedelai, 
sedangkan perlakuan B (100\% Pupuk Guano) menghasilkan tinggi tanaman terendah.

Aplikasi pupuk N,P,K yang diaplikasikan dengan pupuk guano terlihat dapat meningkatkan tinggi tanaman dibandingkan perlakuan dosis pupuk $\mathrm{N}, \mathrm{P}, \mathrm{K}$ saja dan dosis pupuk guano saja. Pemupukan nitrogen akan merangsang pertumbuhan vegetatif dari tanaman sedangkan penambahan unsur hara $\mathrm{P}$ akan menguatkan sistem perakaran tanaman sehingga dapat merangsang pertumbuhan tinggi tanaman.

Pemberian pupuk organik yang diaplikasikan dengan $\mathrm{N}, \mathrm{P}, \mathrm{K}$ dapat meningkatkan tinggi tanaman. Pada perlakuan dosis Guano saja memiliki tinggi tanaman paling rendah dibandingkan perlakuan yang lain, karena kandungan $\mathrm{N}$ pada pupuk guano rendah. Hal ini diduga karena terjadi defisiensi unsur $\mathrm{N}$ karena unsur ini lambat tersedia. Unsur $\mathrm{N}$ ini berperan penting pada fase pertumbuhan vegetatif tanaman.

Pertumbuhan tanaman terjadi karena adanya proses-proses pembelahan sel dan pemanjangan sel dimana proses-proses tersebut memerlukan karbohidrat dalam jumlah besar. Gardner et al. (1991) menyatakan bahwa pertumbuhan dan hasil suatu tanaman dipengaruhi oleh keadaan lingkungan tumbuhnya. Salah satu faktor lingkungan tumbuh yang penting bagi pertumbuhan tanaman adalah ketersediaan unsur hara dan pengendalian organisme pengganggu tanaman.

Indeks Luas Daun. Daun adalah organ fotosintetik tanaman sehingga luas daun yang tercermin dari ILD penting diperhatikan. Nilai ILD selama pertumbuhan tanaman kedelai mengalami peningkatan sesuai bertambahnya umur tanaman, kemudian turun dan ILD maksimum dicapai pada saat jumlah daun dan ukuran daun maksimum (Sumarsono, 2010).

Indeks luas daun optimum untuk pertumbuhan tanaman kedelai varietas Wilis untuk pertumbuhan biji adalah 2,30-3,25 (Indradewa, 1997). Menurut Gardner et al., (1991), apabila luas daun dapat dipertahankan untuk menerima sebagian besar cahaya matahari, maka akan diperoleh laju pertumbuhan tanaman yang maksimum. Pada pengamatan ILD seluruh perlakuan tidak berbeda nyata dan berada dalam kondisi optimum untuk pertumbuhan biji.

Faktor lain yang dapat mengubah nilai ILD adalah kelengasan tanah, yang mempengaruhi jumlah daun dan luas daun. Pada umumnya pupuk organik mengandung hara makro yang rendah, tetapi mengandung hara mikro yang cukup yang sangat diperlukan oleh tanaman. Sebagai bahan pembenah tanah pupuk organik dapat mencegah erosi, mencegah pergerakan permukaan tanah (crusting) dan retakan tanah, mempertahankan kelengasan tanah (Madjid, 2009).

Tabel 3. Pengaruh Beberapa Dosis Pupuk N,P,K dan Pupuk Guano terhadap Indeks Luas Daun.

\begin{tabular}{cc}
\hline \hline Perlakuan & Indeks Luas Daun 8 MST \\
\hline A & $2,60 \mathrm{a}$ \\
B & $2,30 \mathrm{a}$ \\
C & $3,12 \mathrm{a}$ \\
D & $3,02 \mathrm{a}$ \\
E & $2,99 \mathrm{a}$ \\
F & $2,97 \mathrm{a}$ \\
G & $2,89 \mathrm{a}$ \\
H & $2,77 \mathrm{a}$ \\
\hline \hline
\end{tabular}

$\overline{\text { Keterangan: Nilai rata-rata diikuti oleh huruf yang }}$ sama pada kolom yang sama menunjukkan tidak berbeda nyata menurut Uji Jarak Berganda Duncan pada taraf $5 \%$.

Jumlah Bintil Akar Efektif. Pengaruh perlakuan dosis pupuk N,P,K dan pupuk Guano pada jumlah bintil akar efektif terdapat perlakuan yang tidak berbeda nyata. Perlakuan A $(100 \%$ NPK) tidak berbeda nyata dengan B (100\% Pupuk Guano) tetapi berbeda nyata dengan perlakuan lain.

Tabel 4. Pengaruh Beberapa Dosis Pupuk N,P,K dan Pupuk Guano terhadap Jumlah Bintil Akar Efektif (buah)

\begin{tabular}{cc}
\hline \hline Perlakuan & Jumlah Bintil Akar Efektif (buah) \\
\hline A & $13,00 \mathrm{c}$ \\
B & $12,25 \mathrm{c}$ \\
C & $16,00 \mathrm{~b}$ \\
D & $15,25 \mathrm{~b}$ \\
E & $16,00 \mathrm{~b}$ \\
F & $17,75 \mathrm{a}$ \\
G & $15,00 \mathrm{~b}$ \\
H & $18,00 \mathrm{a}$ \\
\hline \hline
\end{tabular}

Keterangan: Nilai rata-rata diikuti oleh huruf yang sama pada kolom yang sama menunjukkan tidak berbeda nyata menurut Uji Jarak Berganda Duncan pada taraf $5 \%$.

Pemberian pupuk $\mathrm{N}, \mathrm{P}, \mathrm{K}$ saja tidak bisa mencukupi kebutuhan hara tanaman tanpa adanya asupan unsur mikro dari Pupuk Guano. Begitu pula dengan perlakuan dengan menggunakan pupuk organik saja, karena pupuk Guano umumnnya merupakan pupuk 
lengkap yang mengandung unsur makro dan mikro tetapi dalam jumlah sedikit (Prihmantoro, 1996). Dari tabel dapat dilihat dosis pupuk $\mathrm{H}$ (50\% N,P,K + 50\% Pupuk Guano) merupakan perlakuan terbaik terhadap jumlah bintil akar efektif yang diikuti dengan jumlah polong isi per tanaman.

Perhitungan bintil akar efektif dilakukan saat umur tanaman 5 MST, akan tetapi banyak bintil akar yang belum efektif. Menurut Adisarwantoro (2005), pembentukan bintil akar terjadi pada umur 4-5 HST yaitu sejak terbentuknya akar tanaman, dan dapat mengikat nitrogen dari udara pada umur 10-12 HST, tergantung kondisi lingkungan tanah dan suhu. Kondisi lingkungan seperti kelembaban yang cukup dan suhu tanah sekitar 25 derajat C sangat mendukung dalam pertumbuhan bintil akar. Suhu rata-rata selama percobaan 27,3 derajat $-31,1$ derajat $C$ menjadi penyebab lambatnya pembentukan bintil akar efetif. Semakin banyak bintil akar efektif maka nitrogen yang diikat di udara semakin banyak, maka dapat merangsang pertumbuhan vegetatif (batang dan daun), serta meningkatkan jumlah anakan dan meningkatkan jumlah polong (Rauf dan Sihombing, 2000).

Jumlah Polong Isi dan Jumlah Polong Hampa. Menurut Suwarno dan Komaruddin Idris (2007), kandungan nitrogen dalam Guano lebih tinggi daripada yang terdapat dalam pupuk kandang, limbah pertanian, maupun sampah kota. Grant dan Flaten (1998) dalam Grant et al., (2002) mengemukakan bahwa unsur hara $\mathrm{N}$ diperlukan untuk menjamin kualitas tanaman yang optimum yang ditunjukkan oleh kandungan protein dari tanaman yang berhubungan langsung dengan suplai N. Penggunaan pupuk organik membuat unsur hara terikat dan tersedia dalam waktu lama, sehingga menyuburkan tanaman.

Data analisis jumlah polong isi per tanaman memperlihatkan unsur hara telah optimal digunakan, dari data menunjukkan perlakuan $\mathrm{H}$ (50\% NPK + 50\% Pupuk Guano) menghasilkan polong isi dan polong hampa yang tidak berbeda nyata dengan perlakuan A (100\% NPK) yang merupakan perlakuan kontrol.

Tingginya jumlah polong hampa pada perlakuan tanpa pemberian pupuk Guano disebabkan karena rendahnya ketersediaan unsur hara mikro. Guano memiliki unsure mikro serta unsur $\mathrm{K}$ yang diperlukan oleh tanaman. Unsur K sangat berperan dalam proses pembentukan polong dan polong bernas pada tanaman kedelai. Semakin tinggi $\mathrm{K}$ maka pembentukan dan pengisian polong semakin berjalan sempurna (Hanibal, 1995).

Tabel 5. Pengaruh Beberapa Dosis Pupuk N,P,K dan Pupuk Guano terhadap Jumlah Polong Isi Per Tanaman (buah) dan Jumlah Polong Hampa (buah).

\begin{tabular}{ccc}
\hline Perlakuan & $\begin{array}{c}\text { Jumlah Polong Isi } \\
\text { Per Tanaman } \\
\text { (buah) }\end{array}$ & $\begin{array}{c}\text { Jumlah Polong } \\
\text { Hampa Per } \\
\text { Tanaman (buah) }\end{array}$ \\
\hline A & $32,00 \mathrm{a}$ & $5,75 \mathrm{a}$ \\
B & $16,50 \mathrm{~b}$ & $1,00 \mathrm{~b}$ \\
C & $34,50 \mathrm{a}$ & $4,00 \mathrm{ab}$ \\
D & $35,00 \mathrm{a}$ & $2,00 \mathrm{~b}$ \\
E & $34,75 \mathrm{a}$ & $3,00 \mathrm{ab}$ \\
F & $34,25 \mathrm{a}$ & $1,50 \mathrm{~b}$ \\
G & $31,25 \mathrm{a}$ & $3,00 \mathrm{ab}$ \\
H & $39,50 \mathrm{a}$ & $3,00 \mathrm{ab}$ \\
\hline
\end{tabular}

Keterangan: Nilai rata-rata diikuti oleh huruf yang sama pada kolom yang sama menunjukkan tidak berbeda nyata menurut Uji Jarak Berganda Duncan pada taraf $5 \%$.

Bobot Biji Per Tanaman, Bobot 100 Biji dan Indeks Panen. Analisis statistik pada bobot biji per tanaman, bobot 100 biji, serta indeks panen menunjukkan bahwa dosis pupuk $\mathrm{N}, \mathrm{P}, \mathrm{K}$ dan pupuk Guano memberikan pengaruh nyata. Perlakuan dengan 100 \% pupuk Guano tanpa pemberian NPK menampakkan hasil paling rendah dan berbeda nyata dengan perlakuan lain.

Tabel 6. Pengaruh Beberapa Dosis Pupuk N,P,K dan Pupuk Guano terhadap Bobot Biji Per Tanaman (g), Bobot 100 Biji (g) dan Indeks Panen.

\begin{tabular}{cccc}
\hline \hline Perlakuan & $\begin{array}{c}\text { Bobot Biji Per } \\
\text { Tanaman }(\mathrm{g})\end{array}$ & $\begin{array}{c}\text { Bobot } 100 \\
\text { Biji }(\mathrm{g})\end{array}$ & $\begin{array}{c}\text { Indeks } \\
\text { Panen }\end{array}$ \\
\hline A & $9,79 \mathrm{a}$ & $10,53 \mathrm{a}$ & $0,48 \mathrm{~b}$ \\
$\mathrm{~B}$ & $5,89 \mathrm{~b}$ & $9,12 \mathrm{~b}$ & $0,40 \mathrm{c}$ \\
$\mathrm{C}$ & $10,25 \mathrm{a}$ & $10,57 \mathrm{a}$ & $0,59 \mathrm{a}$ \\
$\mathrm{D}$ & $8,95 \mathrm{a}$ & $9,73 \mathrm{ab}$ & $0,55 \mathrm{ab}$ \\
E & $9,40 \mathrm{a}$ & $10,55 \mathrm{a}$ & $0,50 \mathrm{~b}$ \\
F & $8,82 \mathrm{a}$ & $10,05 \mathrm{a}$ & $0,48 \mathrm{~b}$ \\
G & $8,75 \mathrm{a}$ & $10,58 \mathrm{a}$ & $0,53 \mathrm{ab}$ \\
H & $9,86 \mathrm{a}$ & $10,05 \mathrm{ab}$ & $0,55 \mathrm{ab}$ \\
\hline \hline
\end{tabular}

Keterangan: Nilai rata-rata diikuti oleh huruf yang sama pada kolom yang sama menunjukkan tidak berbeda nyata menurut Uji Jarak Berganda Duncan pada taraf $5 \%$.

Perlakuan $100 \%$ dosis Guano terlihat menghasilkan bobot biji per tanaman, bobot 100 biji dan indeks panen yang paling rendah dibandingkan perlakuan yang lain.. Penyebab 
dari rendahnya bobot biji per tanaman dan bobot 100 biji adalah terjadinya defisiensi unsur hara, karena kandungan unsure hara makro pada Guano rendah. Hasil bobot biji per tanaman dipengaruhi oleh fotosintesis, dimana proses ini dipengaruhi oleh unsur hara $\mathrm{N}, \mathrm{P}, \mathrm{K}$. Unsur hara $\mathrm{N}$ berperan penting sebagai penyusun protein yang akan digunakan oleh tanaman untuk meningkatkan jumlah polong isi. Unsur P berperan dalam suplai dan transfer energi seluruh proses biokimia tanaman, salah satunya yaitu mempercepat proses pemasakan dan mendorong perkembangan polong sehingga memberi nilai yang tinggi terhadap bobot biji. Unsur $\mathrm{K}$ diperlukan oleh tanaman untuk pembentukan gula dan zat tepung serta mengaktifkan berbagai enzim (Rochman dan Sugiyanta, 2007). Tetapi karena jumlah polong isi perlakuan $100 \%$ dosis Guano rendah maka hasil bobot biji per tanaman, bobot 100 biji dan indeks panen juga rendah.

Perlakuan 50\% N,P,K + 50\% Pupuk Guano memberikan nilai rata-rata yang tidak berbeda nyata dengan perlakuan $75 \% \mathrm{~N}, \mathrm{P}, \mathrm{K}+100 \%$ Pupuk Guano dan perlakuan kontrol $100 \%$ N,P,K. Pupuk Guano yang diaplikasikan dengan pupuk N,P,K dapat memberikan keseimbangan pemupukan, menyeimbangkan proses organik dalam tanah dan merangsang perkembangan mikroorganisme dalam tanah. Pupuk Guano dapat meningkatkan kesuburan tanah sehingga nutrisi tanaman yang diperoleh dari pupuk $\mathrm{N}, \mathrm{P}, \mathrm{K}$ dapat terserap lebih efektif. Setyamidjaja (1986) menyatakan bahwa keseimbangan hara dalam tanah merupakan faktor penting bagi kelancaran metabolisme yang erat hubungannya dengan pertumbuhan tanaman dan produksi tanaman yang dihasilkan

Pada bobot kering 100 biji menunjukkan bahwa perlakuan H $(50 \%$ NPK $+50 \%$ Pupuk Guano) tidak berbeda nyata dengan perlakuan lain termasuk perlakuan A sebagai kontrol. Hal ini disebabkan karena pupuk $\mathrm{N}, \mathrm{P}, \mathrm{K}$ yang dikombinasikan dengan pupuk Guano dapat memenuhi kebutuhan $\mathrm{N}$ pada tanaman, unsur $\mathrm{N}$ merupakan bahan pembentukan protein sehingga unsur ini diperlukan untuk pertumbuhan biji kedelai. Unsur $\mathrm{N}$ juga merupakan komponen esensial dalam asam amino yang menjadi dasar pembentukan protein, juga dalam basa nitrogen yang terdapat dalam asam nukleat dan senyawa yang berkerabat, seperti ATP (Tjitrosomo dkk., 1986) yang akhirnya menambah berat kering biji.

Indeks panen (IP) menggambarkan hasil asimilat yang diperoleh tanaman (Gardner et al,
1991). Nilai IP menunjukkan efisiensi peng-gunaan fotosintat karena hasil fotosintesisnya dapat ditranslokasikan ke organ yang akan dipanen. Pada analisis indeks panen dapat disimpulkan bahwa perlakuan $75 \%$ NPK $+100 \%$ pupuk Guano tidak berbeda nyata dengan perlakuan dosis terendah $50 \%$ NPK $+50 \%$ pupuk Guano.

Pemupukan berimbang merupakan kunci peningkatan efisiensi penggunaan pupuk dan produktivitas tanaman. Pemupukan organik yang dipadukan dengan pupuk $\mathrm{N}, \mathrm{P}, \mathrm{K}$ merupakan pengelolaan hara yang berkelanjutan secara jangka panjang menguntungkan bagi peningkatan kualitas kesuburan tanah yang selanjutnya berpengaruh positif bagi peningkatan produksi tanaman kacang-kacangan. Menurut penelitian Bhattachaqya et al., (2008) penambahan pupuk organik pada rekomendasi pupuk NPK dapat meningkatkan hasil biji dan produktivitas tanah

\section{Kesimpulan}

Aplikasi 8 perlakuan kombinasi pupuk, yang terdiri dari 100\% N,P,K, 100\% Pupuk Guano, 75\% N,P,K $+100 \%$ Pupuk Guano, 50\% N,P,K + 100\% Pupuk Guano, 75\% N,P,K + 75\% Pupuk Guano, $50 \%$ N,P,K + 75\% Pupuk Guano, 75\% N,P,K + 50\% Pupuk Guano serta 50\% N,P,K + 50\% Pupuk Guano memberikan pengaruh terhadap tinggi tanaman, bobot kering tanaman, biomassa tanaman, jumlah bintil akar efektif, jumlah polong isi per tanaman, jumlah polong hampa pertanaman, bobot biji per tanaman, bobot 100 biji, indeks panen, bobot biji per hektar.

Perlakuan 50\% N,P,K + 50\% Pupuk Guano memberikan hasil yang tidak berbeda nyata dengan perlakuan kontrol pada tinggi tanaman, biomassa tanaman, indeks luas daun, jumlah daun, jumlah polong isi per tanaman, jumlah polong hampa per tanaman, bobot biji per tanaman, bobot 100 biji, dan indeks panen. Dengan demikian penggunaan pupuk Guano dapat mengurangi penggunaan pupuk $\mathrm{N}, \mathrm{P}$ dan $\mathrm{K}$.

\section{Daftar Pustaka}

Adiningsih J. S., M. Soepartini, A. Kusno, Mulyadi, dan Wiwik Hartati. 1994. Teknologi untuk Meningkatkan Produktivitas Lahan Sawah dan Lahan Kering. Prosiding Temu Konsultasi Sumberdaya Lahan 
Untuk Pembangunan Kawasan Timur Indonesia di Palu 17-20 Januari 1994.

Adisarwanto, T. 2005. Budidaya dengan Pemupukan yang Efektif dan Pengoptimalan Peran Bintil Akar Kedelai. Penebar Swadaya. Bogor.

Bhattachaqya, R., S. Kundu, V. Prakash, and H.S. Gupta. 2008. Sustainability under combined application of mineral and organic fertilizers in a rainfed soybean- Weat system of the Indian Himalayas. Eurp. J. Agron. 28: 33-46

Gardner, F. P., Pearce, R. B., and Mitchell, R. L. 1991. Fisiologi Tanaman Budidaya. Terjemahan Herawati Susilo. Jakarta: UI Press. Hal 432.

Grant, J., Hatcher, A., Macpherson, P., Schofield, B., 1998. Sufate reduction and total benthic metabolism in Shelf and Slope sediments off Nova Scotia. Vie et Milieu 48 (4), 259269. Dalam Grant et al., 2002. Sediment Properties and Benthic-Pelagic Coupling in The North Water. Department of Oceanography, Dalhousie University, Halifax, Nova Scotia, Canada.

Hanibal. 1995. Pengaruh Pemberian Abu Janjang Kelapa Sawit dan Pupuk P Terhadap Pertumbuhan Serta Hasil Kedelai pada Ultisol. [Tesis]. PPS Unand. Padang. 156 hal.

Indradewa, D. 1997. Indeks Luas Daun Kritik dan Optimum pada Tanaman Kedelai yang Diairi dengan Cara Genangan dalam Parit. Jurnal. Prosiding Seminar Nasional Hasil Penelitian Perguruan Tinggi. Buku V. Departemen Pendidikan dan Kebudayaan. Jakarta. Hal 55-60.

Madjid, Abdul. 2009. Pengelolaan Tanah pada Lahan Kering. Sumatera Selatan: Universitas Sriwijaya.

Mimbar, S. M. 1990. Pemupukan N-Urea melalui Daun pada Kedelai Wilis. Agrivita Vol. 13. Dalam Naskiah. 2007. Pengaruh Inokulasi Rhizobium dan Waktu Pemberian Pupuk N (Urea) terhadap Pertumbuhan dan Hasil Kedelai Di Lahan Sawah setelah Kedelai (Glycine max (L). Merril).

Prihmantoto, H. 1996. Memupuk Tanaman Buah. Cetakan I. Penebar Swadaya. Jakarta.
Rauf, A.W., T. Syamsuddin, dan Sri Rahayu Sihombing, 2000. Peranan Pupuk NPK pada Tanaman Padi. Badan Penelitian dan Pengembangan Pertanian, Loka Pengkajian Teknologi Pertanian Kota Barat, Irian Jaya.

Rochman, H.F dan Sugiyanta. 2007. Pengaruh Pupuk Organik dan Anorganik terhadap Pertumbuhan dan Hasil Padi Sawah (Oryza Sativa L.). Jurnal. Bogor. IPB.

Setyamidjaya, D. 1986. Pupuk dan Pemupukan. Simplex. Jakarta.

Sitompul, S. M 7 B. Guritno. 1995. Analisis Pertumbuhan Tanaman. UGM Press. Yogyakarta.

Sudirja. R. 2007. Standar Mutu Pupuk Organik dan Pembenah Tanah. Modull Pelatihan Pembuatan Kompos. Departemen Tenaga Kerja dan Transmigrasi RI. Balai Besar Pengembangan dan Perluasan Kerja. Lembang.

Suhartina. 2005. Deskripsi Varietas Unggul Kacang-kacangan dan Umbi-umbian. Balai Penelitian Tanaman Kacang-kacangan dan Umbi-umbian. Malang. 154 hal.

Sumarno. 1990. Pembentukan Varietas Unggul Wilis. Bul. Agr. Vol. XV No.3. Balai Penelitian Tanaman Pangan. Bogor.

Sumarsono. 2010. Analisis Kuantitatif Pertumbuhan Tanaman Kedelai. Jurnal. Fakultas Peternakan. Universitas Diponegoro.

Suwarno. 1998. Utilization of Electric Furnage Slag in Agriculture. Doctor Thesis, Graduate School of Agriculture, Tokyo University og Agriculture. Dalam Suwarno dan K. Idris. 2007. Potensi dan Kemungkinan Penggunaan Guano secara langsung sebagai Pupuk Di Indonesia. Jurnal. Fakultas Pertanian IPB. Bogor.

Suwarno dan Komaruddin Idris. 2007. Potensi dan Kemungkinan Penggunaan Guano secara langsung sebagai Pupuk di Indonesia. Jurnal. Fakultas Pertanian IPB. Bogor.

Tjitrosomo, 1986. Botani Umum 2. Bandung: Angkasa. Dalam Naskiah. 2007. Pengaruh Inokulasi Rhizobium dan Waktu Pemberian Pupuk N (Urea) terhadap Pertumbuhan dan Hasil Kedelai Di Lahan Sawah setelah Kedelai (Glycine max (L.) Merril.). 